\title{
POST-HARVEST CONTROL OF AFLATOXIN PRODUCTION IN IN-SHELL MOIST PEANUTS WITH SODIUM ORTHO-PHENYLPHENATE: III. STORAGE TESTS
}

\author{
II. FONSECA; C.R. GALLO; M.A. CALORI-DOMINGUES; E.M. GLORIA; P.J. APPROBATTO; \\ E.L. FONSECA; I.V. ZAMBELLO \\ Departamento de Ciència e Tecnologia Agroindustrial - ESALQ/USP - C.P. 9, CEP: 13418-900-Piracicaba, SP
}

\begin{abstract}
The present experiment aimed to evaluate the effect of sodium ortho-phenylphenate (SOF) appliccation to in-shell moist peanuts for the control of aflatoxin production. Previous studies showed the need to improve the SOP solution distribution on peanut pods to evaluate the product. Thus, in this experiment the place of the spray system was the bag filler pipe of the pre-cleaning machine in the warehouse. In the 1989 rainy season two lots of 120 bags of in-shell moist peanuts were sprayed with 0.5 and $1 \%$ SOP solutions and aflatoxin production was not controlled. In the dry season of 1989 and in the rainy season of 1990, in-shell moist peanuts were sprayed with $5 \%$ SOP solution. The coverage of pods with the solution was efficient, allowing a uniform distribution of SOP solution on the pods. The results showed that only the $5.0 \%$ concentration of SOP solution utilized controlled the external fungal growth when a naked eye observation was made, however did not control aflatoxin production when applied to in-shell moist peanuts, probably due to the internal presence of Aspergillus flavus and because the fungicide could not penetrate inside to reach the kernels.
\end{abstract}

Key words: aflatoxins, peanuts, chemical control, sodium ortho-phenylphenate, post-harvest.

\section{CONTROLE DA PRODUÇÃo DE AFLATOXINAS NO AMENDOIM EM CASCA ÚMIDO COM ORTOFENILFENATO DE SÓDIO: III. TESTES NO ARMAZÉM}

RFSUMO: O presente trabalho teve por objetivo avaliar a eficiência da solução de ortofenilfenato de sódio (OFS), no controle da produção de aflatoxinas quando aplicada no amendoim em casca, úmido. Trabalhos anteriormente realizados, em condiçōes de campo, indicaram a necessidade de otimizar a aplicação da solução, para se poder avaliar a real eficiência dessa substância. Assim. neste experimento, o sistema de pulverização foi adaptado na bica de saída da máquina de pré-limpeza, no armazém. Na safra das águas de 1989, dois lotes de 120 sacos de amendoim em casca úmido foram pulverizados com solução de OFS em concentraçōes de 0,5 e 1,0\% e verificou-se que não houve controle da produçāo de aflatoxinas em ambas as concentrações utilizadas. Nas safras da seca de 1989 e das águas de 1990 o amendoim em casca úmido foi pulverizado com solução de OFS na concentração de 5,0\%. A cobertura das vagens com a solução foi eficiente, permitindo uma distribuição uniforme da soluçāo de OFS sobre as vagens. Os resultados obtidos mostraram que nenhuma das concentrações utilizadas controlou a produção de aflatoxinas, quando aplicadas no amendoim em casca, embora, aparentemente, tenham controlado o crescimento fúngico da parte externa das vagens de amendoim. Provavelmente os fungos aflatoxigênicos já poderiam estar presentes dentro de vagens sadias e desse modo a casca do amendoim poderia ser uma barreira à penetração do fungicida dentro da vagem e atingir as amendoas.

Descritores: aflatoxinas, amendoim, controle químico, pós-colheita, ortofenilfenato de sódio.

\section{INTRODUCTION}

Deterioration of peanuts by fungi is partly due to conditions that favor molding after windrowing and during storage. Peanut contamination with aflatoxins, a toxin produced by Aspergillus flavis and $A$. parasiticus, is a great problem in Brazil, mainly when climatic conditions are adverse during the harvest period, what turns a rapid and efficient drying impossible. Application of fungi- cides at the beginning of windrow or storage periods may reduce this problem (JACKSON, 1965). The chemical treatment efficiency depends on the ability of the sprayed substances to cross the shell barrier. Studies made by JACKSON (1964) showed the presence of considerable fungal contamination on kernel surfaces within intact pods, most probably resulting from the growth and penetration of shell surface inhabitants into lobular spaces. 
Healthy plant tissues can become infected if fungal growth spores become attached to the stigma of developing flowers. The spores may germinate and germ tubes penetrate into the developing seed tissue without causing visible damage (SMITH \& MOSS, 1985).

Mature and freshly harvested peanut pods, sprayed with chemicals, under field conditions, were prevented of $A$. flavus invasion and formation of aflatoxins in kernels (BELL \& DOUPNIK JUNIOR, 1971, 1972; MADAAN \& CHOHANN, 1978). FONSECA et al. $(1992,1994)$, studied during 3 years the spray of sodium ortho-phenylphenate (SOP) solution on moist in-shell peanuts, under field conditions, to verify its effect on the control of aflatoxin production. The results showed that although aflatoxin production was controlled fungal growth was not and it was necessary to improve the coverage of peanut pods with the solution, in order to verify the real efficiency of the SOP.

The aim of this paper was to test the efficiency of SOP sprayed on in-shell moist peanuts during the pre-cleaning operation, when it is believed that the coverage would be better.

\section{MATERIAL AND METHODS}

This experiment was conducted in the peanut producing region of Marilia, SP., Brazil, during the rainy and dry seasons of peanut crops in the years of 1989 and 1990.

Peanuts were dug, windrowed and harvested according to the usual agricultural practices of the region. Daily, after digging and windrowing, samples were taken to monitor moisture content until 14-18\%.

In the 1989 rainy season, three lots were submitted to a pre-cleaning operation in a ventilation machine. Two of them were sprayed with SOP solution at concentrations of $0.5 \%$ and $1.0 \%$ and the third, without treatment, was considered as control. The spraying operation was made in the bag filler pipe by an adapted cross spraying system. In the dry season of 1989 and rainy season of 1990 , two lots were used per season. One was treated with 5\% SOP solution and other considered as the control. Throughout the whole experiment, after the spray operation, stacks of 120 bags of $3 \times 4 \times 10$ bags high were built for each lot. Fifteen samples from each lot were drawn to check moisture and aflatoxin contents to determine the initial conditions of the lots. Sixteen external samples, from each lot, were taken after one month of storage and moisture contents.

In order to measure peanut moisture content a resistance type portable moisture tester (ELOTEST) was utilized in the field. In the laboratory, the oven method (BRASIL, 1976) was used.

The modified methods of PONS JÚNIOR et al. (1966) conjugated with VELASCO \& MORRIS (1976) were utilized to measure aflatoxin content. The modifications were: a) the ratio: peanut kernels /water in the slurry was $1: 1.5$; a total of $50 \mathrm{~g}$ of the slurry, was transferred to $250 \mathrm{ml}$ Erlenmeyer flask and $100 \mathrm{ml}$ acetone was added for extraction; $b$ ) the clean up procedure was made with a $20 \%$ lead acetate solution, without boiling (PONS JÚNIOR et al., 1972); c) the chloroform amount for partition was $2 \times 25 \mathrm{ml}$ (STOLOFF \& SCOTT, 1984).

\section{RESULTS AND DISCUSSION}

The moisture content and aflatoxin contamination of peanuts in treated and control lots are presented in Table 1.

1989 CROPS - Rainy season: The 0.5 and $1.0 \%$ SOP solutions were not efficient to control aflatoxin production. The initial aflatoxin mean values ( $B_{1}+G_{1}$ aflatoxins) of the lot treated with $0.5 \%$ and $1.0 \%$ SOP solution was 114 and 61 $\mu \mathrm{g} / \mathrm{kg}$, respectively. After one and two months of storage the mean values increased to 42,258 and $49,170 \mu \mathrm{g} / \mathrm{kg}$ for $0.5 \%$ SOP and 6,482 and 4,326 $\mu \mathrm{g} / \mathrm{kg}$ for $1.0 \%$ SOP solution. Control lots were initially contaminated with a mean value of 3,335 $\mu \mathrm{g} / \mathrm{kg}$ and after one and two months the mean values were 16,466 and $16,606 \mu \mathrm{g} / \mathrm{kg}$, respectively. In this season heavy rains occurred during the harvest and it was difficult to obtain non contaminated peanuts to start the experiment and thus, the lots were initially contaminated with aflatoxins. SOP solution did not control aflatoxin build up, although was uniform, and the mean values of aflatoxin increased along the storage period.

Dry season: The 5\% SOP solution was used and the results showed that only one sample of the treated lot (after two months of storage) was contaminated with aflatoxins $(37 \mu \mathrm{g} / \mathrm{kg})$, however, also in the control lot, none of the samples were contaminated. Probably the environmental conditions were not favorable to aflatoxin production. It was observed that the peanut pods of 


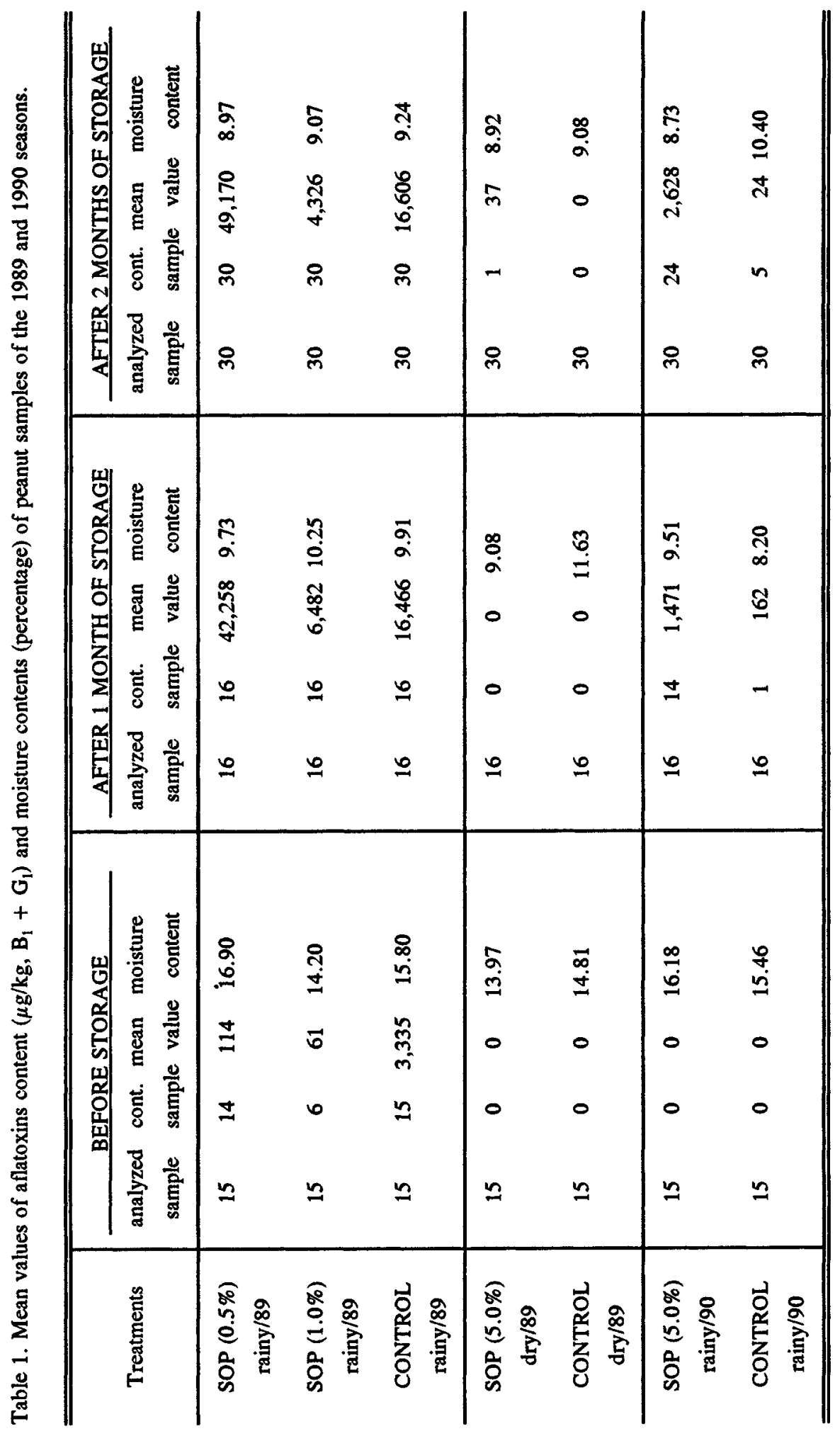


the treated lot did not show external fungal growth by naked eye observation, nevertheless, peanut pods of the control lot showed an intense external fungal growth. This observation could indicate that the SOP solution controlled the external fungal growth. An identification of the fungi that grew on the external surface of the pods was not made.

\section{CROP}

Rainy season: For the 5\% SOP solution used it was observed that the external fungal growth was again controlled, however aflatoxin contamination not. Initially the samples of the treated lot did not show aflatoxin contamination. After one month of storage, 14 samples, out of the 16 analyzed (representing $\mathbf{8 7 . 5 \%}$ ) were contaminated with a mean value of $1,471 \mu \mathrm{g} / \mathrm{kg}$ of aflatoxins and after two months, 24 samples, out of $30(80 \%)$, were contaminated with a mean value of $2,628 \mu \mathrm{g} / \mathrm{kg}$. After one month of storage the control lot showed only one sample, out of $16(6.25 \%)$, contaminated with $162 \mu \mathrm{g} / \mathrm{kg}$ of aflatoxins, and after two months 5 samples, out of $30(17 \%)$, were contaminated with a mean value of $24 \mu \mathrm{g} / \mathrm{kg}$, both levels and percentage of contaminated samples lower than the treated lot. It may be assumed that the aflatoxin contamination probably occurred because of the possibility of the presence of aflatoxigenic fungi inside the sound pods (DIENNER, et al., 1987; JACKSON, 1964; SMITH \& MOSS, 1985) and the shell could have been a barrier for the fungicide to reach the kernels. Other possibility that could have contributed to this contamination is the control of the fungal population on the external surface of the pod and then eliminating the fungal competition. It is known that fungal competition inhibits Aspergillus flavus growth and aflatoxins biosyntheses (NOUT, 1989) and, therefore, the aflatoxigenic fungi that probably were inside the pod could grow intensely and produce large amounts of aflatoxins.

\section{CONCLUSIONS}

The authors conclude that only the $5.0 \%$ SOP solution controlled the external fungal growth when a naked eye observation was made, but did not control aflatoxin production in moist in-shell peanuts probably due to the internal presence of Aspergillus flavus and because the fungicide could not penetrate inside the the pods to reach the kernels.

\section{ACKNOWLEDGMENT}

The authors wish to thank "Fundação Banco do Brasil" (for supporting the experiment); "Máquinas Agrícolas Jacto S.A." for the adaptation of the spraying system and technical support; and the valuable cooperation of the direction and personnel of "Cerealista IHARA Ltda", and "Posto de Sementes" of "Secretaria da Agricultura of the State of São Paulo", both in Marilia, SP, without which this research could not have been made.

\section{REFERENCES}

BELL, D.K.; DOUPNIK JUNIOR, B. Chemical treatment of peanuts in windrow to control Aspergillus flavus and aflatoxins 1. Journal of American Peanut Research and Education Association, v.3, n.1, p.31-32, 1971.

BELL, D.K.; DOUPNIK JUNIOR, B. Chemicals in the windrow for controlling aflatoxins in peanuts. Journal of American Peanut Research and Education Association, v.4, n.1, p.18-20, Aug. 1972.

BRASIL. Ministério da Agricultura. Regras para análise de sementes. Brasília: Departamento Nacional de Produção Vegetal, 1976. 188p.

DIENNER, U.L.; COLE, R.J.; SANDERS, T.H.; PAYNE, G.A.; LEE, L.S.; KLICH, M.A. Epidemiology of aflatoxin formation by Aspergillus flavus. Annual Review of Phytopathology, Palo Alto, v.25, p. $249-270,1987$.

FONSECA, H.; NOGUEIRA, J.N.; CALORIDOMINGUES, M.A.; ZAMBELLO, I.V.; FONSECA, E.L. Post-harvest chemical treatment of in-shell moist peanuts with sodium orthophenylphenate to control aflatoxigenic fungi. I. Field tests. Revista de Microbiologia, São Paulo, v.23, n.4, p.279-283, 1992.

FONSECA, H.; CALORI-DOMINGUES, M.A.; APPROBATTO, P.J.; FONSECA, E.L.; ZAMBELLO, I.V. Post-haverst control of aflatoxin production on in-shell moist peanuts by sodium orthophenylphenate. II. Harvest tests. Revista de Microbiologia, São Paulo, v.25, n.2, p.97-100, 1994.

JACKSON, C.R. Evaluation of fungicides for control of some fungi found on peanuts. Plant Disease Reporter, Washington, n.49, n.11, p.928-931, 1965. 
JACKSON, C.R. Location of fungal contamination or infection in peanut kernels from intact pods. Plant Disease Reporter, Washington, v.48, n.12, p.980-933, 1964.

MADAAN, S.L.; CHOHANN, J.S. Efficacy of anti microbial chemicals to control post harvest occurrence of Aspergillus flavus in groundnut kernels. Indian Phytopathology, New Delhi, v.31, n.1, p.57-59, 1978.

NOUT, M.J.R. Effect of Rhizopus and Neurospora spp. on growth of Aspergillus flavus and A. parasiticus and accumulation of aflatoxin $B_{1}$ in groundnut. Mycological Research, Cambridge, v.93, n.4, p.518523, 1989.

PONS JÚNIOR, W.A.; CUCULLU, A.F.; LEE, L.S.; ROBERTSON, J.A.; FRANZ JUNIOR, A.O. Rapid quantitative TLC method for determining aflatoxins in cottonseed products. Journal of the Association of Official Analytical Chemists, Arlington, v.55, n.4, p.768-774, 1972.
PONS JUNIOR, W.A.; CUCULLU, A.F.; LEE, L.S.; ROBERTSON, J.A.; FRANZ JUNIOR, A.O.; GOLDBLATT, L.A. Determination of aflatoxins in agricultural products: use of aqueous acetone for extraction. Journal of the Association of Official Analytical Chemists, Arlington, v.49, n.3, p.554-562, 1966.

SMITH, J.E.; MOSS, M.O. Control of mycotoxins. In: SMITH, J.; MOSS, M.O. Mycotoxin: formation, analysis and significance. Chichester, John Wiley, 1985. cap.8, p.127-142.

STOLOFF, L.; SCOTT, P.M., eds. 14 (Ed.) Natural poisons. 14.ed. Arlington: AOAC, 1984. cap 26, p.477-500.

VELASCO, J.; MORRIS, S.L. Use of water slurries in aflatoxins analysis. Journal of Agricultural and Food Chemistry, Easton, v.24, n.1, p.86-88, 1976.

Enviado para publicação em 13.12 .93

Aceito para publicação em 12.02 .94 